\title{
IL4 wt Allele
}

National Cancer Institute

\section{Source}

National Cancer Institute. IL4 wt Allele. NCI Thesaurus. Code C50937.

Human IL4 wild-type allele is located in the vicinity of 5q31.1 and is approximately $9 \mathrm{~kb}$ in length. This allele, which encodes interleukin-4 protein, is involved in signal transduction cytokine mediation. 